State of Alaska

Department of Natural Resources

DIVISION OF MINES AND MINERALS
PROPERTY OF

LIBP要繁Y

STATE OF ALASKA

DIVISION OF

GEOLDGICAL SURYEY

MINES AND PETROLEUM BULLETIN

May, 1964

MINING ACTIVITIES
P.O. Box 139I

Juneau, Alaska

$\therefore \because \because \because \because-$

$\because$

Northwestern - Mr. Michael J. O'Shaughnessy, President of Kennecott Copper Corporation, in a letter to Governor William A. Egan reported Kennecott will sink a shaft on its Ruby Creek copper property in the Kobuk region this suminer." The company will move in 4,000 tons of freight and employ 40 to 50 men on the project, according to $\mathrm{Mr}$, O'Shaughnessy.

Word from Nome indicates that shell oil Company has ceased drilling through the ice for the winter on its offshore prospecting permit.

Wayne Chambers "bought Bill Munz's pröperty at Blufe and plans to mine there this sumer.

Southeastern - The Office of Mineral Exploration announced approval of an exploration program proposed by Bonanza Gold Incorporated on a development. program near the old Jumbo Basin copper mine on Hetta Inlet. Prince of Wales Island.. The loan totals about $\$ 60,000$, half of which will be paid by the :ompany.. Work is expected to start this spring.

Coal News - Coal contracts for military use in Alaska to date amount to : 192,000 tons to the Evan Jones Coal Company and 325,000 tons to Usibelli Coall Company. The Usibelli contract is at $\$ 6.05$ per ton compared to

$\$ 6.13$ per ton last year. Vitro Chemical Corporation received a contract for 25,000 tons of coal to be mined from the former Cripple Creek coal lease.

OIL NEWS

Since the last report the following applications for permit to drill have been approved:

Bchrader Unit \#1 - Sinclair Oil \& Gas Corlpany. operator: 682' F.s.L. 2092! F.E.L. Sec 18 T3S R5E UPM. This location lies about 350 miles north of Fairbanks and about 40 miles southeast of Umiat.

Little Twist Unit \#l - Sinclair Oil \& Gas Company operator: 1406' F.E.I. $\because 2053^{\prime}$ F.N.L. Sec 34 T3S R4W UPM. This lockition lies about 400 miles northwest of Fairbanks and about 30 miles southwest of Umiat.

Middle Ground Shoal \#4 - Pan American Petroleum Corporation operator? j60' E.W.L. and $1980^{\circ}$ S.N.L. Sec 31 T9N RI2W SM. This location lieg in Cook Inlet approximately 1 mile north of the Shell Oil Company's MGS \#1 discovery. 
Middle Ground Shoal \#3 - Pan American Petroleum Corporation operator: EEO'N.S.L. and 1980' W.E.L. Sec 19 T9N RI2W SM. This well lies in cook inlet approximately $\frac{1}{4}$ mile east of Pan American's MGS \#l discovery.

\section{Drilling Activity:}

Operator

soco

Pan American Petroleum soco.

Union Oil Company

Mobil Oil Company

Sinclair Oil \& Gas Company
We11 Name \& Number

Beluga River Unit \#14-19

Tyonek state \#2

Naptowne Unit 24-8

Kasilof \#l

Ninilchik Unit \#l

Schrader Unit \#l
Status $4 / 28 / 64$

Drilling

Drilling

Location

Driling

Drilding

P \& A :

Production, Swanson River Field, Hemlock Zone:

Producing Wells

53

March, 1964

Cumulative to April 1, 1964

Production, Kenai Gas Field:

March, 1964

Cumulative to April i, 1964

Production, Stexling aas Field:

March, 1964

1

Cumulative to April 1, 1964

2

Production, Swanson River Gas Field, Kenai Zone:

March, 1964

4

Cumulative to April 1, 1964

Oil-Barre28

Gag (MCF)

235,799 $30,793,935 \quad 6,724,50 ?$

449,58

$6,2,82,72=$

3,907

83,048

395,301

$6,041,893$

Ga's Injection, Swanson River Field, Hemlock Zone:

March, 1964

510,089

Cumulative to April 1, 1964

$8,049,758$

Production, Beluga River Gas Field, Kenai Zone:

Cumulative to April 1, 1964 
U. S. Geological Survey

Bulletin 1043-E, Recognition of Igrieous and Metamorphic Rocks on Aerial Photographs of Chichagof and Kruzof Island, Southeastern Alaska, by J. S. Pomeroy.

Professional Paper 475-D, Short Papers in Geology and Hydrology. "One article in this issue deals specifically with Alaska: Art. 148, by. I... L. Tailleur, "Rich Oil Shale from Northern Aiaska".

Map I-375, Geologic Map and Section of the Chandalar Quadrengle, Alagika by. W.P. Brosge and H. N. Reiser.

\section{WILDCAT WELU SUCCESS RATIO}

The American Association of Petroleum Geologists report that fewer:. exploratory (wildcat) wells were drilled in 1963 than in 1962, but there was a success ratio in 1963 of 18.5 percent over 18.4 percent in 1962. The Alaska success ratio was slightly higher than the national average. The 1963 success ratio: for Alaska was 18.8 percent.

\section{AIME PAPERS AVAILABLE}

Two of the papers presented at the recent Alagka AIME Conference at College contained excellent ideas for using known geological and mineralogical information for prospecting. These should be of wide interest to those concerned with mining exploration in Alaska. We have reproducod these papers in quantity and they are available free on request by mail at our Juneau office, Box 1391, or over-the-counter at our offices at Anchorage, . Fairbanks, and Ketchikan. The titles are "A Possible Guide to Metal Deposits in Alaska" by Charles F. Herbert and "Tectonics and Ore Deposits in Aláska" by Gordon Herreja.

\section{ANCHORAGE: DISTRICT OFFICE OPEN}

The Anchorage District office is now open at $800 \mathrm{I}$ street. The Petroleum, Geology, Mining and Assay Branches are all housed at this address. The $x$-ray spectrograph was removed in good condition from the carthquakeruined. Mines Building and is now. in use. Wet and fire assaying and geochemical analyses. will not be done at the new location. Samples should be sent either to. the Fairbanks or Ketchikan Assay Offices: 
E \& M Metal and Mineral Maxkets, the Wall street Journal, and other recent publications have published articles that indicate metal prices are firming at higher levels. National Lead boosted domestic antimony $3 \frac{1}{2}$ in April. Tungsten moved up 25 . Russia withdrew offers of zinc, lead, plat. inum, and tungsten. Zinc sells in London at an 11-year high of $14 x^{4}$ a pound. Platinum in London now brings $\$ 136$ an ounce. Mercury supplies.are rightening and prices are expected to rise.

Copper is still quoted at $32 \%$ a pound, but prices paid recently were higher. It is expecied that producers in Chile will raise their price 24 a pound. Some sales of refined copper were made at $41 \mathrm{f}$ a pound for delivery in. May and June.

Futures prices for lead are close to 13\%, for zinc 14\%, and copper 35396. A thousand tons of Bolivian antimony was sold in New York for. $\$ 8.20$ per stu. There is apparently a drastic shortage of antimony ore. If this trend continues, some of Alaska's small high grade deposits will become attractive.

The Fairbanks District Manager for the Bureau of Land Management has announced that the State of Alaska has selected lands in the Eagle summit area along the Sieese Highway. The lands are selected under the Alaska stacehood Act which permits the scate to select and obtain patent to public lands of the United States in Alaska, provided that nothing therein contained shall affect any valid existing claim, location or entry under the laws of : the United siates.

The lands selected include the upper drainage of Birch creek from the mouth of Butte creek to the head of Mastodon Fork and all of the Gold Dust Creek and Mastodon Fork drainages. There has been very little mining activity in this area in recent years; however, some placer clain locations have Affidavits of Annual Labor filed up to date.

Any mining claimant within this area who may wish to retain his claim under Federal control rather than uider state control may initiate action to do so by filing his objections with the Land office Manager, Bureau of Land Managemen', 516 second Avenue, Fairbanks, Alaska. This protest should -include the names of the claims involved, where they are recorded, including the document volume and page, and an accurate description of the lands involved. Protests will be recieved until patent issues to the state.

Notice is given that the above described lands have been segregated since February 5, 1962 from all forms of entry, applications, and appropriations under the public land laws, including settlement under the homestead and similar laws, and ander mining laws. Settlements:and Iocations initiated on or after that date are null and void. 
Copper, per $1 b$. Lead, per lb. zinc, per $\mathrm{Ib}$. Tin, per $1 \mathrm{~b}$. Nickel, per Ib. Platinua, per oz. Mercury, per Elask Antimony ore, per untt Beryllium ore, per unit Chrome ore, per long ton Molybdenum conc.. per $1 b$. Titanium ore, per ton Tungsten ore, per unit Silver, New York, par or. Silver, U. S. Treasury, par oz.

\begin{tabular}{c} 
April 27. \\
1964 \\
\hline
\end{tabular}

324

136

13.54

134.754

794

$\$ 88$

\$263-266

$\$ 7.00-8.20$

Nat Quoted

Not Quoted

$\$ 1.55$

\$23-26

\$16-18

220.36

129.290

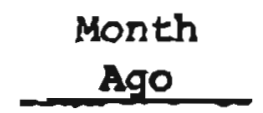

$32 \phi$

134

$13 \%$

134.500

796

$\$ 88$

$\$ 263-273$

lot Quoted

Not Quoted

Lot Quoted

$\$ 1.40$

$\$ 23-26$

\$16-18

129.30

129.296
Year

Ago

$32 \mathrm{C}$

10.54

11.50

$115 \phi$

796

$\$ 77-80$

\$184-187

$\$ 4.25-4.50$

Not Quoted

$\$ 36-38$

$\$ 1.40$

$\$ 23-26$

\$16-18

127.100

$90.5 \%$ 
